\title{
高圧加熱処理した八マチ不可食部添加による 練り製品の製造
}

德 江 千代子, 片 岡 栄子, 杉二 郎* 東京農業大学栄盖学科, *東京農業大学総合研究所

\section{Fish Paste Added with Inedible Portion of "Hamachi" (Young Yellowtail) Treated in Autoclave}

\author{
Chiyoko Tokue, Eiko Kataoka and Jiro Sugi* \\ Department of Nutrition, Tokyo University of Agriculture; *NODAI Research Institute
}

Fish paste products were prepared by adding inedible portion of "Hamachi" (young yellowtail) treated in autoclave to frozen ground pollack meat and minced pork. Products prepared were Tsumireboiled meat balls, Satsumaage-fried meat balls, meat balls cooked in soup, for which softness, smell, flavor, taste are considered important rather than texture, and Kamaboko-steamed fish paste for which flavor and smell are considered essential. Texture was assessed using a rheometer and sensory tests were performed. Fatty acid composition and general components of the inedible and edible portions of "Inada" and "Hamachi" (young yellowtails) were determined by the usual methods. The results obtained were as follows:

1) As for components of "Inada" and "Hamachi", edible portions of both fishes contained larger amount of proteins, and the edible portion of "Inada" and the inedible portion of "Hamachi" contained a large amount of lipid. Ash and calcium were found by severalfold more in the inedible portions of both fishes.

2) Saturated fatty acid content was $33 \%$ for "Inada" and $32 \%$ for "Hamachi" respectively, mono-enoic fatty acid content $45 \%$ and $50 \%$, and poly-enoic fatty acid content $22 \%$ and $18 \%$. Main component fatty acids were $\mathrm{C}_{16: 0}, \mathrm{C}_{18: 1}, \mathrm{C}_{20: 1}, \mathrm{C}_{22: 1}$ and $\mathrm{C}_{22}: 6$. A large amount of docosahexaenoic acid $\left(\mathrm{C}_{22: 6}, 10 \sim 14 \%\right)$ was recognized. Hardly any difference in the fatty acid composition was observed between the edible and inedible portions of both fishes.

3) Samples were prepared by adding inedible portion of "Hamachi" treated in autoclave in amounts corresponding to $5 \%$ and $10 \%$ of the resulting mixture to frozen ground pollack meat and minced pork and the texture characteristics of the mixture were evaluated by Rheometer. Favorable results were obtained in Tsumire when the addition was 5 to $10 \%$ and in Satsumaage with the addition of $5 \%$. The result of the sensory tests in respect of smell, color, taste, hardness and texture revealed excellent result for Tsumire, thus supporting the item with good texture characteristic values. Because samples were treated in autoclave, no fishy smells were evident.

Jpn. J. Nutr., 43 ( 3 ) 149 157 (1985)

緒

言

水産物は，畜産物に劣らず，良質な動物性たん白質の供給源であるが，近年食品として利用される水産資源

Key words : inedible portion of "Hamachi", treatment in autoclave, paste product, frozen ground pollack meat, texture 八マチ不可食部，高圧加熱処理，練り製品，スケトウダラすり身，テクスチャー 


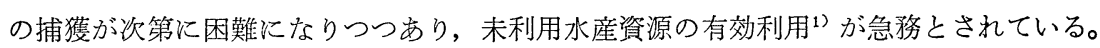

鈴木ら ${ }^{2)}$ はマイワシからの畜肉栐たん白濃縮物の製造時に，桑野ら ${ }^{3)}$ はオキアミたん白濃縮物の製造時に， ともに溶剤で脱脂を行い，ほとんど脂質のないたん白食品素材を製造しているが，これらはいずれも魚体の可 食部のみを主対象としており，不可食部を除いたものである。そこで著者らは，不可食部を脱脂せず，これを 食品の增量剤素材として利用する方法を検討した。

試作および試験方法の概要としては，八マチ不可食部(頭部，内臟，尾䱛その他の鰖，骨部など)を脱脂する ことなく, そのまま利用し, 可食化するため, まず軟化の目的で高圧加熱処理を行った。次に, これらをスケ トウダラの冷凍すり身および豚挽肉に添加して練り製品製造した。試製した練り製品は，“あし”の強さを 必要としない, むしろンフト感, 香り, 味, 色などの要素が重視されるつみれ, さつま揚げ, 肉団子, さらに 味および香りを主にした手製かま济こ様製品の 4 種類に限定して製造し，食品素材としての適正について検討 するため, レオメーターによる物性測定と官能検査を行った。一方，試製した製品は脱脂していない不可食部 を添加しているので，製品の品質保持に悪影響を与えているか否かを知るため，高圧加熱処理して添加した八 マチ不可食部および一般に使用されている可食部について，脂質の性状，脂肪酸組成および一般成分分析など の化学的検討を行ったので, ここに報告する。

\section{実 験 方 法}

\section{1. 原料魚}

実験に供したハマチおよびイナ ダ (Seriola quinqueradiata) は, 1979年 1 月沼津の養殖場で捕獲し たハマチ11尾 (1 尾 $2 \mathrm{~kg}$ 前後)， イナダ 19 尾（1尾 $1 \mathrm{~kg}$ 前後）を 使用した。主原料の冷凍魚肉すり 身については, 日本水産侏敷島丸 が北洋漁場で1978年 3 月26日製造 した冷凍スケトウダラすり身（無 塩）を使用した。

\section{2. 添加用試料の調製}

添加用副原料の調製は Fig.1 1 亿 示した方法で行った。すなわち， ハマチ拉びイイナダ不可食部から， (1) 生鮮試料 (無処理), (2) 高圧加 熱含水試料（缶詰後, $121^{\circ} \mathrm{C}$ で 1 時間加熱), (3) 高圧加熱乾燥試料 $\left(121^{\circ} \mathrm{C}\right.$ で 1 時間加熱後, 凍結乾 燥)の 3 試料を調製した。さらに 可食部孔全く同様に処理して 3 種

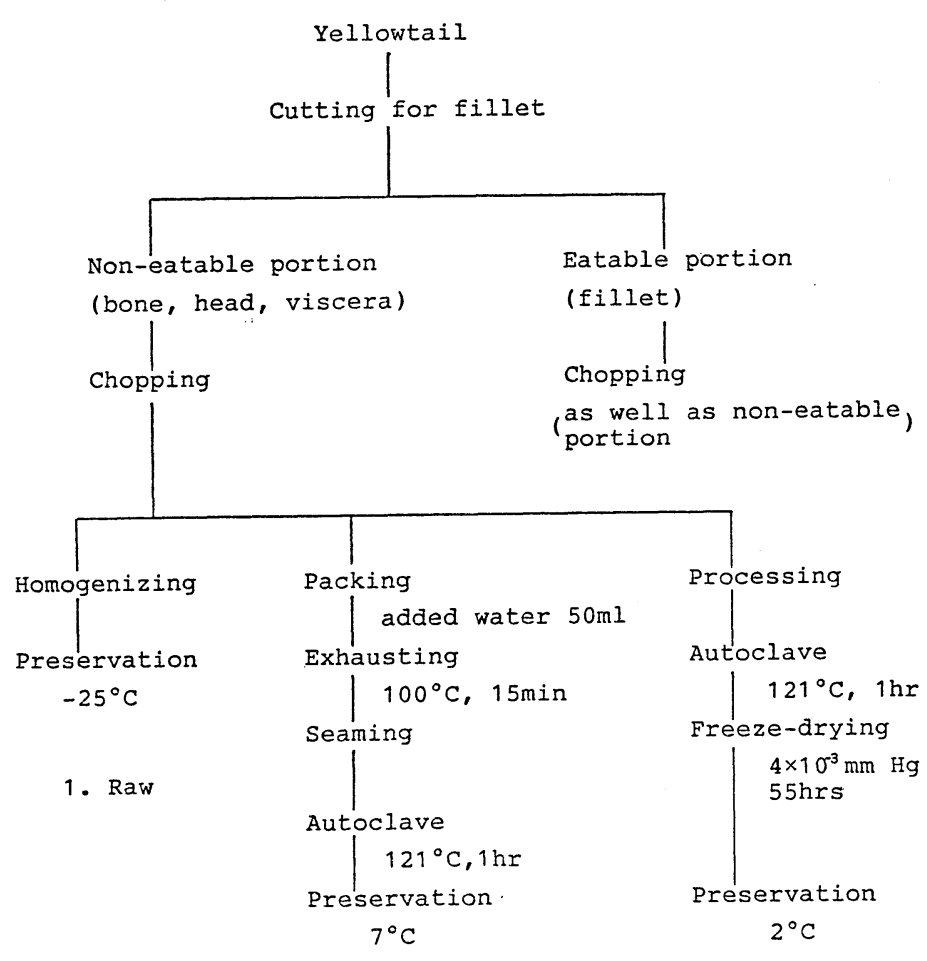

2. Canned

3. Freeze-drying

Fig. 1 Preparation of Sample 
類の試料を調製した。しかし本研究では不可食部の利用を目的としているので，ハマチ不可食部を高圧加熱処 理して軟化させたもの（2)の高圧加熱含水試料）を冷凍スケトウダラすり身および豚挽肉に添加し，練り製品 を製造した。

\section{3. 魚肉および畜肉練り製品の製造}

冷凍スケトウダラすり身および豚挽肉に，前記のハマチ可食部（高圧加熱含水試料）を $5 \%$ および10\%添加 し，次記の方法で，つみれ，かまぼこ，さつま揚げおよび肉団子を試製した。添加対象食品として，前記 4 種 類を選んだ理由は，練り製品として“あし”の強さを必要としない，むしろ香り，味，色，ソフト感，テクス チャーとしてなめらかさなどの要素が重視される食品に目標をおいたためである。

(1) つみれ

無添加試料を作るため，まず，冷凍スケトウダラすり身（以後，すり身） $1 \mathrm{~kg}$ を擂潰機で空ずりし，次に 食塩 $20 \mathrm{~g}$ を2 回に分けて加え, のり状になるまで塩ずりした。さらにつなぎ用として, 卵 $32 \mathrm{~g}$, 者出し汁 30 $\mathrm{g}$ ，小麦粉 $37 \mathrm{~g}$ を加え，混合物が肉のり状になるまで10分間擂潰した。肉のりは長さ $5 \mathrm{~cm}$, 幅 $4 \mathrm{~cm}$ のだ円形 に整形したのち, $80^{\circ} \mathrm{C}$ の熱湯中で 5 分間加熱し製品化した。

なお，ハマチ不可食部 (高圧加熱含水試料) を $5 \%$ あるいは $10 \%$ 添加した試製品については，すり身 $1 \mathrm{~kg}$ に高圧加熱含水試料 $50 \mathrm{~g}$ あるいは $100 \mathrm{~g}$ を同時に加兄，擂潰機で 5 分間空ずりした。以後は無添加試料と同様 な方法で処理し，製品化した。

(2) ゆでかまぽこ

無添加試料として，まずすり身 $1 \mathrm{~kg}$ を擂潰機で空ずりし，次に食塩 $20 \mathrm{~g}$ を 2 回に分けて加え，のり状にな るまで20分間塩ずりをした。さらに副材料としてじゃがいるでん粉 $15 \mathrm{~g}$ ，砂糖 $10 \mathrm{~g}$ みみりん $10 \mathrm{~g}$ を加えて 5 分間擂潰し，その $150 \mathrm{~g}$ を長さ $15 \mathrm{~cm}$ ，幅 $5 \mathrm{~cm}$ のかまぼこ用板に盛り付けて整形し，ラップで包装したの ち, $90^{\circ} \mathrm{C}$ で20分間煮熟してから冷却し，製品化した。

なお，ハマチ不可食部（高圧加熱含水試料）を，5\%あるいは10\%添加した製品については，すり身 $1 \mathrm{~kg}$ に高圧加熱含水試料 $50 \mathrm{~g}$ あるいは $100 \mathrm{~g}$ を同時に加え，5分間空ずりした。以後は無添加試料と同様な方法 で処理し，製品化した。

(3) さつま揚げ

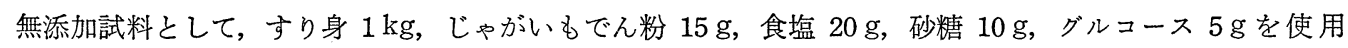
し，かまぼこと同様な方法で擂潰し，長さ $6 \mathrm{~cm}$ ，幅 $5 \mathrm{~cm}$ のだ円形に整形し，製品化した。なお，ハマチ不

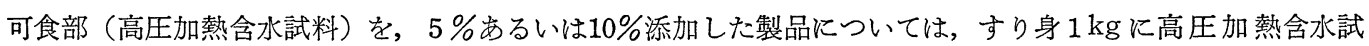
料 $50 \mathrm{~g}$ あるいは $100 \mathrm{~g}$ を同時に加え，擂潰機で 5 分間空ずりした。以後は無添加試料と同様な方法で処理し， 製品化した。

(4) 肉団子

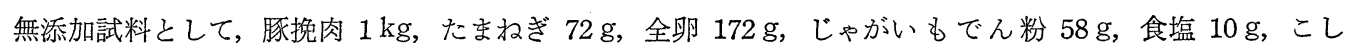
ょら少々，砂糖少々を使用し，まずたまねぎのみじん切りを擂潰機でよくすり，この中に豚挽肉を入れて十分

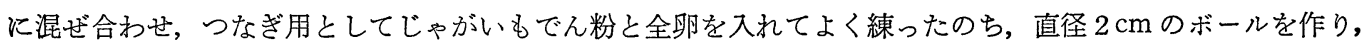
さつま揚げと同様な方法で揚げ，製品とした。

なお，ハマチ不可食部 (高圧加熱含水試料) を，5\%あるいは10\%添加した製品については，まずたまねぎ のみじん切り $72 \mathrm{~g}$ を擂潰機でよくすり，豚挽肉 $1 \mathrm{~kg}$ ，高圧加熱含水試料 $50 \mathrm{~g}$ あるいは $100 \mathrm{~g}$ を同時に入れて 
十分に混ぜ合わせ，つなぎとしてじゃがいもでん粉と全卵を入れ，食塩 $10 \mathrm{~g}$ ，砂糖 少々，こしょう少々を 入れてよく練り，直径 $2 \mathrm{~cm}$ のボール状に整形したのち，さつま揚げと同様な方法で揚げ，製品化した。

\section{4. 化学分析および測定方法}

（1）一般成分の測定

一般成分の分析は常法 ${ }^{4) 5)} に よ り$ 行った。

（2）粗脂肪の一般性状の測定

イナダおよびハマチの処理形態別試料に対し，ソックスレー法によるエーテル抽出を18時間行い，粗脂肪を 抽出した。この粗脂肪の性状測定は，基準油脂分析法 ${ }^{6)}$ に準じて酸価，ヨウ素価就よ゙過酸化物価を測定した。

(3.) 脂肪酸のガスクロマトグラフィー

前記の粗脂肪は，基準油脂分析法 ${ }^{7)}$ に準じ，硫酸ベンゼンメタノール溶液で処理し，脂肪酸のメチルエステ ルを調製した。測定条件は日本電子のガスクロマトグラフ $20 \mathrm{KFP}$ 型を使用し，内径 $3 \mathrm{~mm} \times$ 長さ $200 \mathrm{~cm}$ のス テンレスカラムに $20 \%$ DEGS on 80〜100 mesh を充てん剂として詰め，カラム温度 $190^{\circ} \mathrm{C}$ キャリアーガス $\mathrm{N}_{2}$ の流速 $40 \mathrm{ml} /$ 分，水素炎イオン化検出器を使用し，分析した。

(4) 物性の测定

前記の方法で製造したつみれ，かまぼこ，さつま揚げ，肉団子の各試製品に対し，レオメーター（NRM一 202 J型）による物性測定（硬さ，弾力性，凝集性）を行った。

（5）官能検査

官能検査は，本大学栄養科学生男女10名ずつ計20名により，試製した各種ねり製品について，対照（無添 加）とハマチ不可食部（高圧加熱含水試料）を $5 \%$ あるいは $10 \%$ 添加製品の 3 種類を対にし，香り，色，味， 硬さ，弾力性および総合評価の好ましさの程度について 5 点嗜好尺度法 ${ }^{8)}$ 用いて行い，20名のパネルの評点 から一元配置法による分散分析を行った。

\section{実験結果および考察}

\section{1. イナダおよびハマチの処理形態別試料の一般成分}

Fig. 1 の処理法により，調製したイナダおよびハマチの処理形態別試料の一般成分分析結果の無水物換算値 をTable 1 およびTable 2 に示した。試作した製品の品質保持に大さく影響を与えると考えられる粗脂肪含 量について，可食部と不可食部を比較すると，イナダではあまり差異はなかったが，八マチでは不可食部のほ

Table 1 Chemical components of each part of "Inada"* prepared according to Fig. 1 (Percent in dried matter)

\begin{tabular}{llcccc}
\hline \multirow{2}{*}{ Sample } & & \multicolumn{4}{c}{ Component } \\
\cline { 3 - 6 } & & Crude Fat & Crude Protein & Crude Ash & Calcium (mg\%) \\
\hline Eatable portion & Raw & 25.41 & 63.29 & 4.14 & 271 \\
(fillet) & Canned & 25.25 & 65.71 & 4.17 & 323 \\
\hline Non--eatable & Raw & 23.83 & 49.94 & 13.15 & 3,831 \\
portion & Canned & 24.08 & 49.92 & 13.12 & 3,854 \\
\hline
\end{tabular}

\footnotetext{
* : young yellowtail
} 
Table 2 Chemical components of each part of "Hamachi"* prepared according to Fig. 1 (Percent in dried matter)

\begin{tabular}{lccccc}
\hline \multirow{2}{*}{ Sample } & & \multicolumn{4}{c}{ Component } \\
\cline { 3 - 6 } & & Crude Fat & Crude Protein & Crude Ash & Calcium (mg\%) \\
\hline Eatable portion & $\mathrm{A}$ & 40.29 & 39.94 & 3.05 & 490 \\
(fillet) & $\mathrm{B}$ & 39.79 & 41.42 & 3.65 & 467 \\
& $\mathrm{C}$ & 39.84 & 43.31 & 3.50 & 470 \\
\hline \multirow{2}{*}{$\begin{array}{l}\text { Non-eatable } \\
\text { portion }\end{array}$} & $\mathrm{A}$ & 45.25 & 39.92 & 13.41 & 5,601 \\
& $\mathrm{~B}$ & 44.41 & 40.54 & 11.95 & 5,629 \\
& $\mathrm{C}$ & 44.92 & 42.32 & 12.38 & 5,938 \\
\hline
\end{tabular}

A : Raw, B : Canned, C: Freeze-drying

*: young yellowtail

Table 3 Properties of crude fat extracted from each part of "Inada" prepared according to Fig. 1

\begin{tabular}{lllll}
\hline Properties of crude fat & & AV & IV & POV \\
\hline \multirow{2}{*}{ Eatable portion } & Raw & 2.2 & 160.3 & 4.7 \\
& Canned & 2.9 & 154.7 & 5.4 \\
\hline Non-eatable & Raw & 2.6 & 166.6 & 3.2 \\
portion & Canned & 2.5 & 167.8 & 4.6 \\
\hline
\end{tabular}

AV : Acid value, IV : Iodine value, POV : Peroxide value

Table 4 Properties of crude fat extracted from each part of "Hamachi" prepared according to Fig. 1

\begin{tabular}{lllll}
\hline Properties of crude fat & & AV & IV & POV \\
\hline \multirow{3}{*}{ Eatable portion } & A & 2.8 & 151.2 & 6.2 \\
& B & 2.1 & 150.4 & 8.6 \\
& C & 2.0 & 154.8 & 1.1 \\
Non-eatable & A & 2.8 & 152.1 & 7.2 \\
portion & B & 2.4 & 151.0 & 2.3 \\
& C & 2.6 & 150.0 & 5.4 \\
\hline
\end{tabular}

A, B, C: See Table 2 AV, IV, POV : See Table 2

ろが40〜 45\%と可食部に比べて多かった。さらに両魚種を比較検討すると，イナダに比べてハマチには約 2 倍 量の粗脂肪が含まれていることから，練り製品原料として使用する場合には，脂質の酸化に注意する必要があ ることがわかった。粗たん白質は，両部位間では，イナダにおいては可食部のほうが不可食部に比べて10\%以 上多かったが，ハマチではほとんど差異がなかった。灰分は，イナダおよびハマチの不可食部が当然ながら可 食部の $3 \sim 4$ 倍, カルシウムは10倍以上であった。

\section{2. 粗脂肪の一般性状}

試料中の粗脂肪は, 多量の高度不飽和脂肪酸を含んでいるので, 急速に酸化され, 製品の色, 味, 香りなど に悪影響を与えることが予測される。そこで抽出した粗脂肪の化学的性状を測定した。イナダの処理形態別試 料から抽出した粗脂肪の性状をTable 3, 八マチについてはTable 4 に示した。不可食部ではハマチの高圧 
Table 5 Fatty acid composition of crude fat extracted from various portions of "Inada" prepared according to Fig. 1

\begin{tabular}{cccccc}
\hline \multirow{2}{*}{ Fatty acid } & \multicolumn{2}{c}{ Non-eatable portion } & & \multicolumn{2}{c}{ Eatable portion } \\
\cline { 2 - 3 } \cline { 5 - 6 } & \multicolumn{1}{c}{$\mathrm{A}$} & $\mathrm{C}$ & & $\mathrm{A}$ & $\mathrm{B}$ \\
\hline $\mathrm{C}_{14}: 0$ & 5.52 & 6.25 & & 5.56 & 5.16 \\
$14: 1$ & 1.54 & $\operatorname{tr}$ & & $\operatorname{tr}$ & $\operatorname{tr}$ \\
$16: 0$ & 18.55 & 16.69 & & 19.38 & 19.33 \\
$16: 1$ & 8.95 & 5.50 & & 8.33 & 8.02 \\
$17: 0$ & 2.53 & 1.32 & & 2.10 & 1.63 \\
$18: 0$ & 5.12 & 3.77 & & 5.54 & 5.17 \\
$18: 1$ & 18.14 & 19.20 & & 18.99 & 19.27 \\
$18: 2$ & 2.25 & 1.73 & & 2.16 & 1.92 \\
$20: 0$ & 1.62 & 1.34 & & 1.38 & 1.41 \\
$20: 1$ & 6.18 & 13.25 & & 7.83 & 8.21 \\
$20: 5$ & 1.75 & 11.72 & & 1.56 & 6.45 \\
$22: 1$ & 10.86 & 7.70 & & 11.53 & 8.23 \\
$22: 5$ & 2.52 & 1.69 & & 1.70 & 1.21 \\
$22: 6$ & 14.05 & 9.84 & & 13.82 & 13.90 \\
\hline
\end{tabular}

A, B : See Table 2

Table 6 Fatty acid composition of lipid extracted from various portions of "Hamachi" prepared according to Fig. 1

\begin{tabular}{ccccccccc}
\hline \multirow{2}{*}{ Fatty acid } & \multicolumn{3}{c}{ Non-eatable portion } & & \multicolumn{3}{c}{ Eatable portion } \\
\cline { 2 - 4 } \cline { 6 - 7 } \cline { 6 - 7 } & $\mathrm{A}$ & $\mathrm{B}$ & $\mathrm{C}$ & & $\mathrm{A}$ & $\mathrm{B}$ & $\mathrm{C}$ \\
\hline $\mathrm{C}_{14}: 0$ & 6.02 & 5.70 & 5.90 & & 6.37 & 7.31 & 6.29 \\
$14: 1$ & $\operatorname{tr}$ & $\operatorname{tr}$ & $\operatorname{tr}$ & & 1.32 & 1.18 & $\operatorname{tr}$ \\
$16: 0$ & 18.0 & 18.47 & 17.47 & & 18.96 & 17.48 & 17.53 \\
$16: 1$ & 9.23 & 9.25 & 8.32 & & 7.15 & 8.16 & 7.66 \\
$17: 0$ & 2.15 & 2.28 & 2.00 & & 1.81 & 1.82 & 1.94 \\
$18: 0$ & 3.87 & 4.21 & 4.40 & & 4.25 & 3.81 & 4.31 \\
$18: 1$ & 18.62 & 19.14 & 18.84 & & 18.27 & 19.57 & 19.50 \\
$18: 2$ & 2.42 & 2.60 & 2.11 & & 2.17 & 2.22 & 2.27 \\
$20: 0$ & 1.40 & 1.74 & 1.40 & & 1.43 & 1.42 & 1.50 \\
$20: 1$ & 11.22 & 7.37 & 10.65 & & 11.96 & 11.15 & 11.05 \\
$20: 5$ & 1.35 & 1.52 & 1.83 & & 1.21 & 1.46 & 1.56 \\
$22: 1$ & 11.50 & 12.03 & 13.20 & & 12.01 & 12.39 & 12.43 \\
$22: 5$ & 3.34 & 2.72 & 2.07 & & 2.40 & 2.54 & 2.54 \\
$22: 6$ & 11.04 & 12.42 & 11.93 & & 11.24 & 10.22 & 10.22 \\
\hline
\end{tabular}

A, B, C : See Table 2

加熱含水試料が最も良質であり, 酸価 2.4 ，ヨウ素価 151.0 , 過酸化物価 2.3 と粗脂肪の劣化が少なかったの でつみれ，かまぼこ，さつま揚げ，肉団子などの添加用原料として用いることにした。

\section{3. イナダおよびハマチの処理形態別試料から得た粗脂肪の脂肪酸組成}

脂質の安定性は，脂質を構成する脂肪酸組成によって強く影響されるので，この脂肪酸組成は脂質の含量と ともに加工製品の品質保持の観点から重要な要素となる。イナダの処理形態別試料より得た粗脂肪の脂肪酸組 
成は, Table 5 に示し, ハマチについてはTable 6 に示した。いずれも 主要構成脂肪酸は $\mathrm{C}_{16}: 0, \mathrm{C}_{18}: 1, \mathrm{C}_{20: 1}, \mathrm{C}_{22: 1}, \mathrm{C}_{22}: 6$ であった。さらにイ ナダとハマチについて検討してみると，飽和脂肪酸がそれぞれ $33 \%$ そ $32 \%$ ， モノェン酸が $45 \%$ と $50 \%$ ，ポリェン酸が $22 \%$ と18\%であり，ポリェン酸の らちドコサヘキサェン酸（DHA）が10１4\%拉よび10～12\% 含まれてい た。これはプロスタグランディン (PG) に変化し, 血栓症や心筫梗塞の

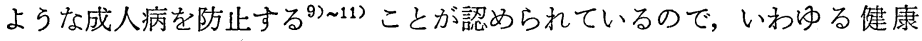
食品の素材としてよいのではないかと思われる。しかし，ドコサへキサエ ン酸は 6 個の二重結合を有しているので著しく不安定であり, 急速に酸化 され, 製品の品質保持に悪影響を与えるので, 酸化に対する対策が重要で あると考えられる。

\section{4. 試作練り製品の物性}

八マチ不可食部の高圧加熱含水試料の $5 \%$ あるいは10\%を冷凍すり身に 添加し，つみれ，かまぼこ，さつま揚げおよび肉団子を試製し，これらの 物性の測定結果をTable 7 に示した。

つみれの場合, 硬さについては, 対照に比べて, 不可食部 $5 \%$ 添加区, 10\%添加区と混入割合が増すごとに硬度が減少したが，弾力性と凝集性に おいては，混入割合が増加するに伴って，測定值が大きく低下した。八、 チ不可食部高压加熱含水試料を $5 \%$ あるいは $10 \%$ 添加した試料は, Table 2 の結果より油に換算すると，1.2\%あるいは2.4\%添加したものと同じと 考学られるので，かまぼこなど魚肉練り製品の物性は ${ }^{12)}$, 脂質含量が高い ほど弾力性が低下するといわれているが，本実験でも同じような傾向を示 した。

さつま揚げに括いては，不可食部を $5 \%$ 添加したものが，硬度，弾力性， 凝集性ともに対照よりやや高い值を示した。

肉団子については，硬さにおいて，3試料間にほとんど差異がなかった が，弾力性と凝集性においては，不可食部の混入割合を増すに伴って低い 数値を示した。

上記 4 種類の試製品をレオメーターで測定した結果, 硬度, 弾力性, 凝 集性がいずれも対照区より不可食部添加区のほうが高い数值を示したもの は，つみれだけであった。そこで，さらに不可食部の混入割合を $20 \%, 30$ \%，50\%と増加したつみれを試製したが，20\%以上添加の場合は，混入割 合を増すにつれて，測定値が大きく減少した。

\section{5. 一元配置による分散分析}

冷凍すり身にハマチ不可食部の高圧加熱含水試料を $5 \%$ あるいは $10 \%$ 添 加し，試製したつみれ，かまぼこ，さつま揚げおよび肉団子の食味の嘴好 特性を20名のパネルの評点から一元配置法による分散分析 ${ }^{8)}$ を行い，それ

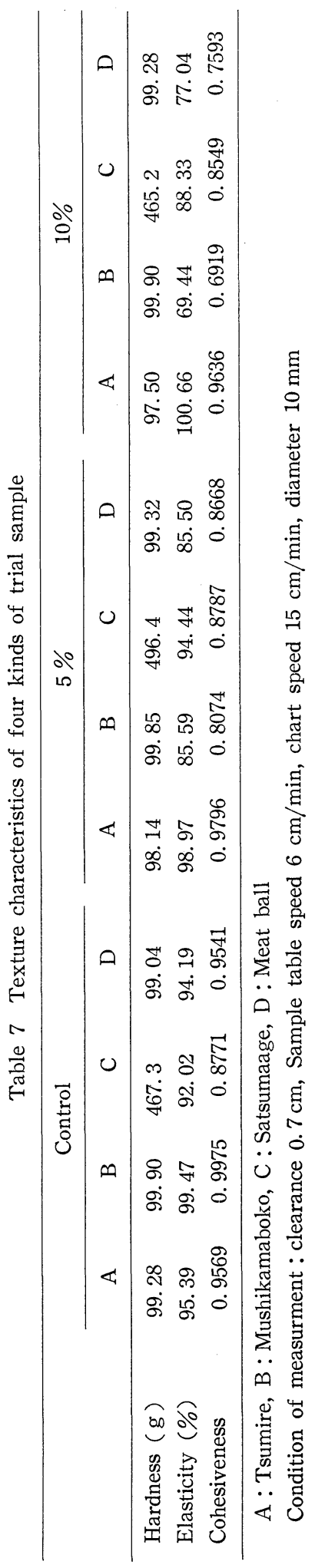


Table 8 Analysis of variance for sensory attributes of paste product

\begin{tabular}{lcccc}
\hline \multirow{2}{*}{ Sensory attributes } & \multicolumn{4}{c}{ Variance ratio $F_{0}$} \\
\cline { 2 - 5 } & Tsumire & Kamaboko & Satumaage & Meat ball \\
\hline Odor & 2.92 & 1.12 & 1.91 & 6.49 \\
Color & 0.67 & 11.15 & 0.51 & 9.12 \\
Taste & 3.59 & 1.89 & 5.84 & 6.73 \\
Hardness & 1.30 & 3.23 & 26.41 & 10.30 \\
Elasticity & 0.37 & 4.97 & 15.17 & 3.76 \\
Overal evalution & 0.99 & 1.22 & 12.91 & 6.08 \\
\hline
\end{tabular}

Significant at the $5 \%$ level $\mathrm{F}_{57}^{2}(0.05)=3.32$

らの $\mathrm{F}_{0}$ 值をTable 8 に示した。

総合評価において，つみれとかまぼこにおいては，危険率 $5 \%$ で有意差は認められなかった。つみれについ ては，喍好特性のうち，味にわずかであるが有意差が認められたが，対照区より不可食部添加区のほうがうま 味ここくかあって拈いしく，吸物に使用すると効果的であった。なお，不可食部の添加率を20\%，30\%，50\% と増加したつみれにおいては，20\%添加試料では危険率 5\%で有意差は認められなかった。しかし，30\%およ び50\%添加試料では, 有意差が大きくなる傾向を示した。かまぼこについては, 色と弾力性に有意差が認めら れ，色は“非常に悪い”と評洒された。このことは，対照区のかまぼこの白さと比較すると，不可食部を入れ たかまぼこは, 褐色がかった灰色になるため, 従来のかまぼこのイメージと食い違ったためだと思われる。次 に総合評価で有意差が認められたさつま揚げでは，香りと色については，評点がよかったが，味，硬さ，弾力 性については評点の低下傾向が大きかった。肉団子については，全ての項目について有意差が認められた。特 にテクスチャーにおいては, 畜肉が与える感覚とはやや異なっていた。なお高圧加熱含水試料を添加したため, 魚臭については全く感じられなかった。今後は，さらにその他の練り製品やソーセージ，ハムなどの幅広い加 工食品の試製および量産の利用面についても検討したいと考えている。

\section{要 約}

冷凍スケトウダラすり身および豚挽肉にハマチ不可食部の高圧加熱含水試料を添加して，練り製品を製造し た。すなわち, “あし”の強さを必要としない, むしろソフト感, 香り, 味, 色などの要素が重視されるつみれ, さつま揚げ，肉団子さらに味および香りを主にした手製かまぼこ様製品の 4 種類に限定して製造し，レオメー ターによるテクスチャー測定と官能検査を行った。一方, 添加用イナダおよび八マチの不可食部と可食部につ いては，脂肪酸組成と一般成分分析を行い，次の結果を得た。

1）イナダおよび八マチの一般成分については，たん白質含量は可食部のほうが多く，脂質については，イ ナダでは可食部が多く，八マチでは不可食部のほうが多く認められた。灰分，カルシウムについては，両魚種 とも不可食部のほうが数倍多く認められた。

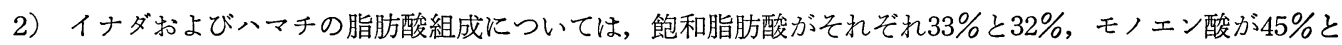
$50 \%$ ，ポリエン酸が $22 \%$ と18\%であり，その主要な構成脂肪酸は， $\mathrm{C}_{16}: 0, \mathrm{C}_{18: 1}, \mathrm{C}_{20: 1}, \mathrm{C}_{22: 1}, \mathrm{C}_{22: 6}$ で, 多量 のドコサヘキサエン酸（C $\left.\mathrm{C}_{22}: 6 ， 10 〜 14 \%\right)$ が認められた。イナダおよび八マチ不可食部と可食部の差は, ほと んど認められなかった。 
3）冷凍スケトゥダラすり身および豚挽肉に，八マチ不可食部の高圧加熱含水試料を $5 \%$ および $10 \%$ 添加し てレオメーターによるテクスチャー測定を行った。つみれについては 5 １0\%添加，さつま揚げについては 5 \%添加によい結果が得られた。官能検査による食味評価を行った結果は, 香り, 色, 味, 硬さ, 弾力性および 総合評価の各項目において，つみれが良好な結果を示し，テクスチャー特性值の裏づけを得た。なお高圧加熱 含水試料を添加したため，魚臭については全く感じられなかった。

本報告の概要については，第27回日本食品工業学会大会（昭和55年 3 月）に执いて発表した。

文献

1）佃 信夫：日食工誌，27，50～59（1980）

2）岡崎恵美子, 神名孝一, 鈴木たね子 : 日水誌, 46, 727〜 732（1980）

3）桑野和民, 津久井亜紀夫, 三田村敏男 : 日水誌, 46, 711 715 (1980)

4）永原太郎，岩尾裕之，久保彰治：食品分析法, pp. 100 143（1966）柴田書店

5）小原哲二郎, 鈴木隆雄, 岩尾裕之：食品分析ハンドブック, pp. 263〜266（1975）建帛社

6）日本油化学協会：基準油脂分析試験法, $2 \cdot 4 \cdot 1-71 \sim 2 \cdot 4 \cdot 12-71$ (1977)

7）日本油化学協会 : 基準油脂分析試験法, $2 \cdot 4 \cdot 20-71$ (1977)

8）島田保子, 川端晶子, 龟城和子, 村山篤子 : 最新調理学実験, pp. 144 148 (1975) 学建書院

9）稲嶺成男，片平亮太：ニューフードインダストリー，26，16１8（1984）

10）露木英男 : 栄養学雑誌, 42, 81 82（1984）

11）秦 和彦: 食品と科学, 5, 46 (1984)

12）岡田 稔, 横関源延, 衣卷豊輔：魚肉衫り製品, pp. 50～51（1974）恒星社厚生閣

（受付：昭和59年10月27日） 